\title{
Occupational Diseases and Illnesses in Manufacturing Industries in Adamawa State: Causes and Effects
}

\author{
Atsumbe, B.N ${ }^{1}$. Maigida, J. F. ${ }^{1}$ Abutu, Francis ${ }^{1}$ Amine, J. D ${ }^{2}$. Enoch, E. B ${ }^{3}$. \\ ${ }^{1}$ Department of Industrial \& Technology Education, Federal University of Technology, Minna,Niger \\ State, Nigeria. \\ 2. Department of Mechanical Engineering, Federal University of Agriculture,Makurdi,Benue State, Nigeria. \\ ${ }^{3}$ Department of Technology Education, Federal University of Technology, Yola,Adamawa State,Nigeria.
}

\begin{abstract}
The high incidence rate of fatal diseases, illnesses and injuries prevalent among industrial workers and the consequent effect requiring days away from work to allow the worker time to recuperate is alarming and counterproductive. This research study was therefore designed to investigate the occupational health practices in manufacturing industries in Adamawa State. Four research questions were formulated to guide the study. The study was conducted among manufacturing industries within Adamawa State. Purposive sampling technique was used to select 200 industrial workers for the study. A 60-item questionnaire was used to collect the required data. Mean and standard deviation were used for data analysis. Data analysis revealed that a lot of fatal occupational diseases and illnesses exist in the industries; the possible sources of these diseases and illnesses are also numerous; it was also discovered that the level of industries compliance to occupational health regulations is poor with a consequent increase in fatalities. The study also recommended that: Federal Government and other appropriate authorities should ensure, monitoring and strict compliance with the occupational health regulations as contained in the factory Act of 1990 to reduce loss of workdays usually associated with victims of occupational diseases, illnesses and injuries.
\end{abstract}

\section{Introduction}

Manufacturing industries in Adamawa State just like most industries in Nigeria in a bid to provide maximum customer satisfaction continuously undergo innovations. These innovations in technology has led to rapid advancement in industrial manufacturing processes with a consequent increase in newer types of dangers to human health (Belanger, 1981). New types of occupational diseases, illnesses and injuries are also emerging without the workers been aware that new technology brings new problems (David,2006).).Eilbert (1996) described occupational health as the promotion and maintenance of the highest degree of physical, mental and social well-being of workers in all occupations. Manufacturing industries can be described as the industries that focuses on the transformation of raw materials and information into goods for the satisfaction of human needs. Diseases associated with manufacturing industries are also termed industrial diseases. Occupational health practices otherwise known as health safety practices encompasses all activities geared towards ensuring workers safety and wellbeing in all occupations.

Wikipedia (2011) describes work-related diseases or occupational disease and illness as any chronic ailment that occur as a result of work or occupational activity. It is an aspect of occupational safety and health. Diseases compensated by national workers compensation authorities are often termed occupational diseases. Jain (2010) stress the need for all factories to adhere strictly to the provisions of the factories Act 1990 which is a law regulating safety, health and welfare of workers in factories. He further defines a factory as a place where manufacturing processes is carried on with or without the aid of power with ten or more workers working or was working on any day of the preceding 12 months. However, many industries in many countries do not offer compensations for certain diseases like musculoskeletal disorders caused by heavy labour work. Therefore, the term work-related diseases are utilized to describe diseases of occupational origin. Work-related diseases include both compensable and non-compensable diseases of occupational origins.

An occupational disease is typically identified when it is shown that it is more prevalent in a given body of workers than in the general population, or in other worker populations. Health hazard review by the National Institute for Occupational Safety and Health (NIOSH, 1989) attributed most fatal occupational diseases, illnesses and injuries among industrial workers to exposure to dangerous substances like chemicals and various types of dusts particle due to poor handling and ignorant. Work place exposures involve many individual chemicals and combinations. Ezeonu and Ezejiofor (1999) revealed that occupational diseases and illnesses also result from changes that occur in chemical formulations. Also most of the chemicals found in industries have not been tested for carcinogenicity or toxicity, nor do they have Occupational Safety and Health Administration (OSHA) permissible exposure limits (PELs) or NIOSH recommended exposure limits (RELs). 
Epidemiologic and industrial hygiene research studies by Richard and Faye (2000) revealed that occupational diseases and illnesses have numerous adverse effects on human health such as respiratory effects, chronic cough, dermatologic effects, reproductive effects, repeated trauma disorder, musculoskeletal disorders, cancer, injuries resulting from cataract/poor sight, skin diseases/disorders, and genetic mutation resulting from nuclear radiation. According to Donald (2011) some well-known occupational diseases include: occupational lung diseases and occupational skin diseases. Occupational lung diseases are caused by excessive exposure and inhalation of harmful substances like dust and gases. Lung diseases have adverse respiratory effects like chest tightness, shortness of breath and pulmonary disorders. Occupational lung disease, include asbestosis common among asbestos miners, black lung disease among coal miners, silicosis among quarrying and cement workers, and byssinosis among workers in the cotton textile industry. Occupational asthma is also a respiratory disease leading to nasal irritation, coughing and wheezing. Asthma is common among workers handling a high concentration of dust particles.

Contact dermatitis and occupational skin diseases are generally caused by chemicals and having wet hands for long periods while at work. Skin diseases or disorders include contact dermatitis, urticaria, sunburn, skin cancer, eczema or rash caused by primary irritatants and sensitizers. Occupational skin diseases is more common among the following occupations: hairdressing, catering, health care, printing, metal machining, motor vehicle repair and construction.

According to Nivedita (2008) other work-related diseases of concern include: carpal tunnel syndrome among persons who work in the poultry industry and information technology industry. Computer vision syndrome among persons using computers for long hours; and lead poisoning affecting workers in water industries, cement industries, sugar industries, Aluminum industry and other industries that processes or uses lead compounds. Radiation sickness is also common among x-ray workers in hospitals or nuclear industry.

Many epidemiologic studies have attributed excess occupational deaths to occupational diseases, illnesses and injuries associated with manufacturing industries (Stewart and Rice, 1990). Osrisakwe (2007) is of the opinion that the increasing rate of fatalities due to occupational diseases and illnesses is a clear indication that workers are not fully aware of the potential sources of occupational diseases and illnesses associated with poor health practices in their places of work. Mojiminiyi ,Morenu, Ibrahim, Njoku (2008) lamented on the counter productive nature in which these fatal diseases and illnesses usually require a worker to stay away from work for some days to allow the worker time to recover with its consequent effect of low productivity due to loss of work days. Another occupational health measurement for cases with days away from work is musculoskeletal disorders (MSDs). The Bureau of Labor Statistics (2012) defines MSDs as cases in which the nature of injury or illness is sprains, strains, tears; back pain, hurt back; soreness, pain and hurt, except the back; carpal tunnel syndrome; hernia; or musculoskeletal system and connective tissue diseases and disorders where the event or exposure leading to the injury or illness was bodily reaction, bending, climbing, crawling, reaching, twisting; overexertion; or repetition.

A lot of workers work for survival without paying attention to the health hazard surrounding their work places (Kilpikari, 1982). Industrial workers are also ignorant of the responsibilities and obligation of the industries in terms of health care provision for workers. It is the poor occupational health practices prevalent in the manufacturing industries in Adamawa State that gave birth to this study.

\section{Research Questions}

Four research questions were formulated to guide the study:

1. What are the occupational diseases and illnesses associated with manufacturing industries?

2. What are the possible sources of occupational diseases and illnesses in manufacturing industries?

3. What is the level of industries compliance to occupational health regulations?

4. What are the safety educational health measures to reduce occupational diseases and illnesses?

\section{Methodology}

A survey research design was employed for the study. The area of study was Adamawa State. Purposive sampling was used to collect data from 200 industrial workers spread across Adamawa State comprising of Savannah Sugar, Zerawo Aluminum Factory, Faro Water Producing Company, Nima Form Producing Industry and Ashaka Cement. A five point structured questionnaire containing 60 items was used to collect data from the respondents. The questionnaire was validated by three experts in the Department of Industrial and Technology Education of Federal Univeristy of Technology, Minna. The data obtained from the industrial workers was analyzed using mean $(\mathrm{x})$ and standard deviation. For the decision rule: items with mean score below 3.00 were rejected while those with mean score of 3.00 and above were regarded as accepted. 


\section{Research Question 1}

What are the occupational diseases and illnesses associated with manufacturing industries?

Table 1:

Mean (x) Responses and Standard Deviation (SD) of Management Staff and Factory Workers on the Occupational Diseases and Illnesses Associated with Manufacturing Industries.

\begin{tabular}{|c|c|c|c|c|c|c|c|c|}
\hline $\mathbf{S} / \mathbf{N}$ & ITEMS & $\overline{\mathbf{X}}_{1}$ & $\mathbf{S D}_{1}$ & $\overline{\mathbf{X}}_{2}$ & $\mathbf{S D}_{2}$ & $\overline{\mathbf{X}}_{\mathrm{t}}$ & $\mathbf{S D}_{\mathrm{t}}$ & REMARK \\
\hline$\overline{1}$ & Occupational asthma & 4.80 & 0.60 & 3.81 & 0.40 & 4.31 & 0.50 & Accepted \\
\hline 2 & Occupational lung diseases & 4.68 & 0.30 & 3.04 & 0.10 & 3.86 & 0.20 & Accepted \\
\hline 3 & $\begin{array}{l}\text { Occupational skin diseases } \\
\text { and skin cancers }\end{array}$ & 4.71 & 1.20 & 3.10 & 0.30 & 3.91 & 0.75 & Accepted \\
\hline 4 & Occupational dermatitis & 4.68 & 0.36 & 3.41 & 0.70 & 4.05 & 0.54 & Accepted \\
\hline 5 & Welder's arc eye & 4.71 & 1.21 & 4.02 & 0.65 & 4.37 & 0.93 & Accepted \\
\hline 6 & $\begin{array}{l}\text { Lead poisoning and toxic } \\
\text { substance poisoning }\end{array}$ & 4.34 & 0.83 & 3.81 & 1.27 & 4.08 & 1.05 & Accepted \\
\hline 7 & Computer vision syndrome & 4.68 & 0.32 & 4.05 & 0.81 & 4.37 & 0.56 & Accepted \\
\hline 8 & Radiation sickness & 4.34 & 1.00 & 3.47 & 0.72 & 3.91 & 0.86 & Accepted \\
\hline 9 & Carpal tunnel syndrome & 4.00 & 1.39 & 4.06 & 0.63 & 4.03 & 1.01 & Accepted \\
\hline 10 & $\begin{array}{l}\text { Occupational noise-induced } \\
\text { deafness }\end{array}$ & 4.01 & 1.29 & 4.75 & 0.74 & 4.38 & 1.02 & Accepted \\
\hline 11 & $\begin{array}{l}\text { Musculoskeletal disorders of } \\
\text { the upper limb }\end{array}$ & 4.10 & 0.75 & 3.71 & 0.11 & 3.91 & 0.43 & Accepted \\
\hline 12 & $\begin{array}{l}\text { Ulceration of the eye due to } \\
\text { hydrocarbon exposure }\end{array}$ & 4.20 & 1.30 & 4.01 & 0.64 & 4.11 & 0.97 & Accepted \\
\hline 13 & Compressed air illness & 4.71 & 0.45 & 4.36 & 0.81 & 4.54 & 0.63 & Accepted \\
\hline 14 & Excessive heat diseases & 4.56 & 0.56 & 4.70 & 0.72 & 4.32 & 0.64 & Accepted \\
\hline 15 & Tuberculosis & 4.71 & 0.45 & 4.45 & 1.05 & 4.58 & 0.75 & Accepted \\
\hline
\end{tabular}

Analysis on table 1 shows that the management staff and factory workers accepted the 15 items presented to them to be among the occupational diseases and illnesses associated with manufacturing industries with mean score ranging between $4.05-4.48$.

Research Question 2

What are the possible sources of occupational diseases and illnesses in manufacturing industries?

Table 2:

Mean (x) Responses and Standard Deviation (SD) of Management Staff and Factory Workers on the Possible Sources of Occupational Diseases and Illnesses in Manufacturing Industries.

\begin{tabular}{lllllllll}
\hline $\mathbf{S} / \mathbf{N}$ & \multicolumn{1}{c}{ ITEMS } & $\overline{\mathbf{X}}_{\mathbf{1}}$ & $\mathbf{S D}_{\mathbf{1}}$ & $\overline{\mathbf{X}}_{\mathbf{2}}$ & $\mathbf{S D}_{\mathbf{2}}$ & $\overline{\mathbf{X}}_{\mathbf{t}}$ & $\mathbf{S D}_{\mathbf{t}}$ & REMARK \\
\hline 16 & Exposure to toxic chemicals. & 4.74 & 0.68 & 4.65 & 0.70 & 4.69 & 0.69 & Accepted \\
17 & $\begin{array}{l}\text { Exposures to excess heat. } \\
18\end{array}$ & 4.64 & 0.48 & 3.73 & 0.71 & 4.21 & 0.59 & Accepted \\
19 & $\begin{array}{l}\text { Exposure to excess noise. } \\
\text { Inhalation of excess dust particles. }\end{array}$ & 4.17 & 1.10 & 4.80 & 1.41 & 4.49 & 1.25 & Accepted \\
20 & $\begin{array}{l}\text { Excessive exposure to poisonous } \\
\text { gases. }\end{array}$ & 4.34 & 0.96 & 4.05 & 0.41 & 4.66 & 0.78 & $\begin{array}{l}\text { Accepted } \\
21\end{array}$ \\
$\begin{array}{l}\text { Having wet hands for too long at } \\
\text { workplace. }\end{array}$ & 4.09 & 1.39 & 3.90 & 1.07 & 3.99 & 1.23 & Accepted \\
22 & $\begin{array}{l}\text { The use or handling of substances } \\
\text { that are skin irritants and }\end{array}$ & 3.77 & 0.36 & 3.75 & 0.69 & 3.76 & 0.52 & Accepted \\
23 & $\begin{array}{l}\text { sensitizers. } \\
\text { Exposure to welding arc. }\end{array}$ & 4.68 & 0.42 & 4.10 & 0.74 & 4.39 & 0.68 & Accepted \\
24 & $\begin{array}{l}\text { Using computers for very long } \\
\text { hours. }\end{array}$ & 3.70 & 1.12 & 3.45 & 1.15 & 3.57 & 1.13 & Accepted \\
Exposure to excess dose of & 4.04 & 0.78 & 4.40 & 0.67 & 4.22 & 0.87 & Accepted \\
nuclear radiations. & Exposure to animal waste. & 4.74 & 1.01 & 4.12 & 0.64 & 4.43 & 0.83 & Accepted \\
\hline
\end{tabular}


Occupational Diseases And Illnesses In Manufacturing Industries In Adamawa State: Causes And

\begin{tabular}{|c|c|c|c|c|c|c|c|c|}
\hline 27 & $\begin{array}{l}\text { Unduly heavy physical labor } \\
\text { among laborers and mechanics. }\end{array}$ & 4.68 & 0.45 & 3.40 & 0.55 & 3.94 & 0.51 & Accepted \\
\hline 28 & $\begin{array}{l}\text { Careless handling of compressed } \\
\text { air or use of compressed air to } \\
\text { clean the body. }\end{array}$ & 4.11 & 1.36 & 3.71 & 1.15 & 3.91 & 1.25 & Accepted \\
\hline 29 & $\begin{array}{l}\text { Exposure to harmful fumes and } \\
\text { vapors. }\end{array}$ & 4.35 & 0.96 & 3.65 & 1.14 & 4.00 & 1.05 & Accepted \\
\hline 30 & $\begin{array}{l}\text { Excessive exposure to pathogens } \\
\text { such as bacteria, fungi and } \\
\text { viruses. }\end{array}$ & 4.34 & 0.96 & 4.05 & 0.41 & 4.19 & 0.55 & Accepted \\
\hline
\end{tabular}

From the analysis of table 2, the respondents unanimously accepted all the items as possible sources of occupational diseases and illnesses in manufacturing industries with mean score between 3.57 - 4.69.

\section{Research Question 3}

What is the Level of Industries Compliance to Occupational Health Regulations?

\section{Table 3:}

Mean (x) Responses and Standard Deviation (SD) of Management Staff and Factory Workers on the Level of Industries Compliance to Occupational Health Regulations?

\begin{tabular}{|c|c|c|c|c|c|c|c|c|}
\hline $\mathbf{S} / \mathbf{N}$ & ITEMS & $\overline{X_{1}}$ & $\mathrm{SD}_{1}$ & $\bar{X}_{2}$ & $\mathrm{SD}_{2}$ & $\bar{X}_{t}$ & $\mathbf{S D}_{\mathrm{t}}$ & REMARK \\
\hline 31 & $\begin{array}{l}\text { Provision of standard industrial } \\
\text { hospitals. }\end{array}$ & 2.75 & 0.23 & 2.60 & 0.14 & 2.68 & 0.19 & Rejected \\
\hline 32 & $\begin{array}{l}\text { Provision of regular medical } \\
\text { check up for industrial workers. }\end{array}$ & 2.71 & 0.49 & 2.42 & 0.31 & 2.57 & 0.40 & Rejected \\
\hline 33 & $\begin{array}{l}\text { Provision of clean drinking water } \\
\text { for workers. }\end{array}$ & 4.68 & 0.98 & 3.71 & 0.38 & 3.93 & 0.43 & Accepted \\
\hline 34 & $\begin{array}{l}\text { Provision of latrines, urinals, } \\
\text { spittoons. }\end{array}$ & 4.63 & 1.55 & 3.91 & 0.48 & 4.27 & 1.01 & Accepted \\
\hline 35 & $\begin{array}{l}\text { Effective disposal of waste and } \\
\text { effluents. }\end{array}$ & 4.51 & 0.14 & 3.78 & 1.15 & 4.14 & 1.32 & Accepted \\
\hline 36 & $\begin{array}{l}\text { Construction of overhead } \\
\text { discharge of dangerous fumes and } \\
\text { dust. }\end{array}$ & 4.66 & 0.78 & 3.51 & 0.70 & 4.08 & 0.74 & Accepted \\
\hline 37 & $\begin{array}{l}\text { Provision of medical assistance to } \\
\text { victims of work-related diseases. }\end{array}$ & 4.71 & 1.68 & 3.62 & 1.25 & 4.16 & 1.47 & Accepted \\
\hline 38 & $\begin{array}{l}\text { Provision of regular periodic } \\
\text { safety and health education } \\
\text { training to create awareness on } \\
\text { work-related diseases, illnesses } \\
\text { and injury. }\end{array}$ & 2.81 & 0.61 & 2.30 & 0.13 & 2.56 & 0.37 & Rejected \\
\hline 39 & $\begin{array}{l}\text { Provision of sufficient numbers of } \\
\text { nose and mouth respirators. }\end{array}$ & 2.65 & 0.52 & 2.13 & 0.43 & 2.39 & 0.48 & Rejected \\
\hline 40 & $\begin{array}{l}\text { Provision of adequate } \\
\text { compensation to diseased victims } \\
\text { or workers. }\end{array}$ & 2.61 & 0.51 & 2.12 & 0.39 & 2.37 & 0.45 & Rejected \\
\hline 41 & $\begin{array}{l}\text { Provision of complete personal } \\
\text { protective equipments to all } \\
\text { factory workers. }\end{array}$ & 2.74 & 0.62 & 2.14 & 0.31 & 2.45 & 0.47 & Rejected \\
\hline 42 & $\begin{array}{l}\text { Provision and maintenance of } \\
\text { industrial diseases and illnesses } \\
\text { registers. }\end{array}$ & 4.61 & 0.70 & 4.40 & 0.71 & 4.51 & 0.71 & Accepted \\
\hline 43 & $\begin{array}{l}\text { Licensing and approval of plants } \\
\text { or factories. }\end{array}$ & 4.27 & 0.86 & 4.21 & 1.13 & 4.24 & 0.99 & Accepted \\
\hline 44 & $\begin{array}{l}\text { Provision of sufficient quality } \\
\text { drinking water. }\end{array}$ & 4.80 & 0.80 & 4.10 & 0.45 & 4.45 & 0.63 & Accepted \\
\hline 45 & $\begin{array}{l}\text { Provision of adequate ventilation } \\
\text { in factory work rooms. }\end{array}$ & 4.71 & 1.75 & 3.70 & 0.67 & 4.21 & 1.20 & Accepted \\
\hline
\end{tabular}


Analysis on table 3 shows that the respondents accepted that 9 of the items were being complied to by industries with mean score ranging between 3.93 - 4.51 while they rejected items $31,32,38,39,40,41$ with mean score ranging between 2.67-2.68.

\section{Research Question 4}

What are the safety educational health measures to reduce occupational diseases and illnesses?

Table 4: Mean (x) Responses and Standard Deviation (SD) of Management Staff and Factory Workers on the Safety Educational Measures to Reduce Occupational Diseases and Illnesses.

\begin{tabular}{|c|c|c|c|c|c|c|c|c|}
\hline $\mathbf{S} / \mathbf{N}$ & ITEMS & $\overline{\mathbf{X}}_{1}$ & $\mathbf{S D}_{1}$ & $\overline{\mathbf{X}}_{2}$ & $\mathrm{SD}_{2}$ & $\overline{\mathbf{X}_{\mathrm{t}}}$ & SD $_{\mathrm{t}}$ & REMARK \\
\hline 46 & $\begin{array}{l}\text { Organizing } \text { periodic } \text { health } \\
\text { education training on the } \\
\text { awareness of occupational } \\
\text { diseases, illnesses and injuries. }\end{array}$ & 4.26 & 0.81 & 3.92 & 0.84 & 4.09 & 0.58 & Accepted \\
\hline 47 & $\begin{array}{l}\text { Launching a personalized } \\
\text { programme on work-related } \\
\text { diseases and illnesses. }\end{array}$ & 3.96 & 0.13 & 4.41 & 0.48 & 4.19 & 0.31 & Accepted \\
\hline 48 & $\begin{array}{l}\text { Carrying out mass training on } \\
\text { industrial health hazards in work } \\
\text { places. }\end{array}$ & 4.29 & 0.81 & 3.98 & 0.59 & 4.11 & 0.70 & Accepted \\
\hline 49 & Eliminating industrial bottlenecks. & 4.37 & 0.54 & 4.10 & 0.58 & 4.24 & 0.56 & Accepted \\
\hline 50 & $\begin{array}{l}\text { Teaching workers to practice } \\
\text { industrial hygiene. }\end{array}$ & 4.67 & 0.59 & 3.67 & 0.70 & 4.19 & 0.65 & Accepted \\
\hline 51 & $\begin{array}{l}\text { Using occupational health experts } \\
\text { and safety specialist and } \\
\text { supervisors to educate industrial } \\
\text { workers. }\end{array}$ & 4.24 & 0.92 & 3.67 & 1.01 & 3.96 & 0.97 & Accepted \\
\hline 52 & $\begin{array}{l}\text { Promoting epidemiologic research } \\
\text { studies on work-related diseases } \\
\text { and illnesses. }\end{array}$ & 4.56 & 0.88 & 3.11 & 0.81 & 3.84 & 0.85 & Accepted \\
\hline 53 & $\begin{array}{l}\text { Evaluation of health and safety } \\
\text { programs. }\end{array}$ & 4.53 & 1.77 & 4.81 & 0.74 & 4.67 & 1.26 & Accepted \\
\hline 54 & $\begin{array}{l}\text { Evaluation of hazardous } \\
\text { exposures of harmful substances. }\end{array}$ & 4.46 & 0.73 & 4.21 & 1.07 & 4.33 & 0.90 & Accepted \\
\hline 55 & $\begin{array}{l}\text { Periodic evaluation of data } \\
\text { collected on occupational diseases } \\
\text { and illnesses victims. }\end{array}$ & 4.65 & 0.73 & 4.43 & 0.90 & 4.54 & 0.82 & Accepted \\
\hline 56 & $\begin{array}{l}\text { Conducting toxicological studies } \\
\text { in work places. }\end{array}$ & 4.41 & 0.52 & 3.97 & 0.75 & 4.10 & 0.64 & Accepted \\
\hline 57 & $\begin{array}{l}\text { Conducting risk assessment } \\
\text { research in factories. }\end{array}$ & 3.55 & 0.28 & 3.06 & 0.23 & 3.31 & 0.26 & Accepted \\
\hline 58 & $\begin{array}{l}\text { Conducting detail analysis of } \\
\text { industrial diseases, illnesses and } \\
\text { injuries on victims. }\end{array}$ & 3.40 & 0.44 & 3.23 & 0.42 & 3.32 & 0.43 & Accepted \\
\hline 59 & $\begin{array}{l}\text { Teaching health and safety } \\
\text { principles using appropriate } \\
\text { instructional aids like posters, } \\
\text { safety signs, bulletins and films. }\end{array}$ & 3.51 & 0.44 & 3.20 & 0.35 & 3.36 & 0.40 & Accepted \\
\hline 60 & $\begin{array}{l}\text { Using the industrial workshop } \\
\text { classrooms to teach and train } \\
\text { workers on how to administer } \\
\text { various types of first aids in } \\
\text { workplaces. }\end{array}$ & 3.57 & 0.39 & 3.03 & 0.23 & 3.30 & 0.31 & Accepted \\
\hline
\end{tabular}

The analysis in table 4 shows that both categories of staff accepted all the items with mean score ranging between 3.30-4.67. The respondents agreed that the 15 items should be part of the safety educational health measures to reduce occupational diseases and illnesses in industries.

\section{Findings}


The following were the findings from the study:

On the occupational diseases and illnesses associated with manufacturing industries, both respondents accepted that all the items presented in table 1 are among the occupational diseases and illnesses associated with manufacturing industries in Adamawa State.

As regards the possible sources of occupational diseases and illnesses in manufacturing industries, both respondents accepted that all the items analyzed are among the potential or possible sources of occupational diseases and illnesses in manufacturing industries.

Also as to the level of industries compliance to occupational health regulations as contained in the Factory Act of 1990, the respondents accepted 9 of the items and rejected 6 of the items with mean score ranging between 2.61-2.81.

While on the safety educational health measures to reduce occupational disease and illnesses, both respondents accepted all the items presented to them as appropriate measures which when in place will go a long way to reduce work-related diseases.

\section{Discussion of Findings}

With regard to table 1, the findings of the study revealed that the occupational diseases and illnesses associated with manufacturing industries are among the diseases and illnesses itemize in the instrument and their mean responses is between $4.01-4.46$. This is in agreement with Donald (2011) who identifies and classify occupational diseases associated with manufacturing industries into: occupational lung diseases, occupational skin diseases and other work-related diseases. He further explained that occupational lung diseases include asbestosis, black lung disease, silicosis and byssinosis while the occupational skin diseases include eczema, urticaria, sunburn and skin cancer. Other work related diseases he identified include occupational asthma, carpal tunnel syndrome, computer vision syndrome and lead poisoning. This implies that a lot of diseases and illnesses are of occupational origin which threatens the health of workers and also hinders smooth industrial activity and consequently reduce production.

The result of table 2 indicated that the 15 items identified in the instrument were accepted by both categories of staff as being the potential or possible sources of occupational diseases and illnesses in manufacturing industries in Adamawa State of Nigeria. They have a high mean response ranging between 4.09 - 4.49. This can be buttress by the health hazard review by the National Institute for Occupational Safety and Health (NIOSH, 1989) who attributed most of the fatal occupational diseases, illnesses and injuries among industrial workers to exposure to dangerous substances like poisonous chemicals and various poisonous types of dust particles due to poor handling resulting from workers ignorant of the health hazards associated with these harmful substances. He stressed the need for workers to always handle chemicals with caution because new technologies bring about changes in individual chemicals, chemicals combinations and chemical formulations.

The findings in table 3 showed that both categories of industrial workers accepted that 9 of the items were being complied to by industries while 6 of the items were rejected. The items accepted have high mean score ranging between $4.08-4.50$ while the rejected items have mean score ranging between $2.61-2.81$. This is a clear evidence that most industries and employers of labour do not strictly or fully adhere or comply to the occupational health regulations as contained in the Factory Act of 1990 (Jain, 2010). Table 3 further reveals the non compliance of industries to: provision of standard medical care, sufficient personal protective equipments, and adequate compensation of diseased workers, periodic safety and health education training and health hazard awareness in the industries.

Findings as evident in table 4 revealed that the industrial workers accepted all the items presented to them as suitable safety educational health measures which if properly put in place will go a long way to reduce (if not eliminate) occupational diseases and illnesses in industries in Adamawa State of Nigeria. These safety educational health measures will greatly help to remove ignorant of health hazards or dangers surrounding industrial work places in the mind of industrial workers and promote good health and physical wellbeing of workers. This is in line with Eilbert (1996) who in is struggle and support to promote good health among industrial workers describe occupational health as the promotion and maintenance of the highest degree of physical, mental and social wellbeing of workers in all occupations. He further stressed that high productivity can only be achieved in industries when workers have good health of mind and body.

\section{Conclusion}

Based on the findings of the study, it is evident that a lot of occupational diseases and illnesses exist in manufacturing industries, More work-related diseases and illnesses are even likely to emerge as innovations in technology continues. The potential or possible sources of industrial diseases and illnesses are also numerous such that the industrial workers are not even fully aware of the health hazards surrounding their work. Level of compliance of industries to occupational health regulations is also poor with a consequent increase in occupational deaths, disabilities, injuries, diseases, illnesses and low productivity. 
Findings further revealed that, it is important to periodically conduct epidemiologic, toxicological and industrial hygiene research studies in Nigerian industries to continually assess and reassess the risk of new and emerging diseases among factory workers. More detail analysis of workers diseases, illnesses, and injuries are also needed to identify areas for workers training and other preventive or control measures. The result of future industrial research studies should be closely monitored to determine whether a policy frame work or recommendations to Federal regulatory agencies in industries should be developed to reduce and control diseases Therefore adopting good safety educational health measures will help to promote occupational health practices which will also lead to reduction in occupational diseases and illnesses in manufacturing industries in Adamawa State.

\section{Recommendations}

Based on the findings of the study, the following recommendations were made:

1. The ministry of employment, labour and productivity should ensure strict compliance of industries to the occupational health regulations as contained in the Factory Act of 1990.

2. The management of manufacturing industries should incorporate occupational health hazards awareness training as a major content in the orientation programmes organize for new industrial workers. This will expose workers to the work-related diseases, illnesses and other health dangers surrounding their work.

3. The Federal Government should ensure that the industries provide standard medical care, sufficient personal protective equipment and adequate compensation to diseased or accident victims.

4. Factories should also be legally licensed and approved by the Federal Government and other appropriate authority before commencing operation, The factories Act of 1990 should also be periodically reviewed to make the penalty harsher for defaulting industries.

5. Industries should periodically sponsor and conduct epidemiologic research studies on work-related diseases and illnesses. Toxicological studies and detail analyses of industrial diseases and illnesses should also be conducted in industries.

6. Management should periodically organize a training forum in the industrial workshop classroom where workers will be taught occupational health and safety principles, and administration of first aid using real life health equipments and appropriate instructional aid.

7. Industries should periodically evaluate hazardous exposures to harmful substances. This will enable them to have knowledge of the permissible limits of exposure to avoid spread of diseases and illnesses.

\section{References}

[1]. Belanger, P.L. (1981). Health hazard evaluation report. Center for disease control, NIOSH report no. HETA 81 - 107.

[2]. Bureau of Labour Statistics (2012). Technical Information. Retrieved 27th December, 2012 from www.bls.gov.

[3]. David A.G.(2006). Occupational contribution to chronic cough. Journal of occupational medicine and toxicology. Retrieved $27^{\text {th }}$ December, 2012 from www.occup/med.com.

[4]. Donald, H. (2011). Occupational diseases. Retrieved $27^{\text {th }}$ December, 2012 from www. wikibooks.org.

[5]. Ezeonu FC,Ezejiofor TI,(1999).Biochemical Indicators of occupational health in cement industry workers in Nigeria.Science Total Environ 5:238(2-3): 275-8

[6]. Eilbert, A. (1996). Occupational health hazards. Retrieved $27^{\text {th }}$ December, 2012 from www.occup/med.com.

[7]. FRN (1990). The laws of the Federation of Nigeria: Factories Act, Lagos, Federal Ministry of Justice.

[8]. Jain, R.K. (2010). Production Technology. New Delhi: Khanna publishers.

[9]. Kilpikari, I. (1982). Occupational contact dermatitis among rubber workers. Contact Dermatitis 8:359-362.

[10]. Mojiminiyi FB,Morenu JA,Ibrahim MT \& Njoku CH(2008).Effects of cement dust exposure on haematology and liver function parameters of cement factory workers in Nigeria. Nigeria Journal of physiologic science. 23(1-2):111-4.

[11]. Nivedita L. B.(2008). Injuries, Illnesses, and Fatalities in Food Manufacturing industries. Retrieved 27th December, 2012 from Www.bls.gov.

[12]. NIOSH (1989). Hazard evaluation and technical assistance report: Goodyear Tire and Rubber Company. NIOSH Report no. HETA $88-159$.

[13]. Osrisakwe OE.(2007).Liver and kidney function tests among workers in chemical industries in Nigeria.Journal of toxicology and industrial health.23(3):161-5.

[14]. Richard,W.N..\& Faye,L.R.( 2000) .Epidemiologic research report in industries.Cincinati,US division of standards development \& technology transfer (DSDTT) publication.

[15]. Stewart, P.A. and Rice, C. (1990). A source of exposure data for occupational epidemiology studies. Applications of occupational environmental hygiene 5(6): $359-363$.

[16]. Wikipedia (2011). Work-related diseases, industries. Retrieved $27^{\text {th }}$ December, 2012 from www.wikibooks.com. 